\title{
Can Rituximab Induce Long-Term Disease Remission in Patients with Intra-Ocular Non-Infectious Inflammation?
}

\author{
Oren Tomkins-Netzer ${ }^{a, b}$ Simon R.J. Taylor ${ }^{a-c}$ Sue Lightman ${ }^{a, b, d}$ \\ a Royal Surrey County Hospital, Egerton Road, Guildford, ${ }^{\mathrm{b}}$ Moorfields Eye Hospital, ' Division of Immunology and \\ Inflammation, Faculty of Medicine, Imperial College London, and d UCL Institute of Ophthalmology, London, UK
}

\section{Key Words}

Rituximab · Uveitis · Intra-ocular inflammation - CD20 .

Birdshot chorioretinopathy $\cdot$ Remission

\begin{abstract}
Treatment of non-infectious uveitis is based primarily on the use of systemic corticosteroids and second-line immunosuppressive drugs. However, their extensive side effect profile, particularly for steroids, has led to the increased use of other immunosuppressive drugs, as sparing capacity agents. Rituximab is an anti-CD20 chimeric antibody, often given as a single course of 2 infusions, resulting in complete depletion of peripheral mature B cells. While it is licensed to treat refractory systemic lymphoma patients, it has also shown promising results in systemic auto-immune diseases, where a single course of treatment is able to achieve long-term clinical remission. Treatment with rituximab has been reported for various ocular conditions, suggesting it may be effective in inducing long-term disease control and other systemic immunosuppressive agents can be reduced or discontinued. When disease relapse occurs, a further course or courses can be given with good results. This review summarizes the current evidence regarding the role of rituximab in treating non-infectious uveitis.

(c) 2013 S. Karger AG, Basel
\end{abstract}

\section{Introduction}

Non-infectious uveitis accounts for up to $10 \%$ of pathologies leading to blindness [1]. Treatment is primarily centred on controlling the inflammation and preventing any lasting damage that may result in reduced vision. Corticosteroids remain the mainstay treatment of noninfectious uveitis achieving rapid control of ocular inflammation [2]. However, their attendant side effects have led to the continued search for 2nd-line immunosuppressive drugs that can act as steroid-sparing agents. Many different drugs originally used for systemic autoimmune and neoplastic diseases are available to help control ocular inflammation and lower steroid levels. Most of these systemic immunomodulatory drugs used in ophthalmology have been adopted from other specialties, such as rheumatology, and while their safety profiles make them valid alternatives to long-term high-dose corticosteroids, systemic side effects still prove problematic for a significant proportion of patients [3]. Biological agents target specific molecules, making them effective immunomodulating agents with a relatively high safety profile. Of these, rituximab, a chimeric monoclonal antibody directed against CD20 achieves disease control after a single course, with patients symptom free under either no or significantly reduced treatment. Here we present a short case report demonstrating our use of rituximab for

Prof. Sue Lightman

Moorfields Eye Hospital

162-165 City Road

London EC1V 2PD (UK)

E-Mail s.lightman@ucl.ac.uk 
non-infectious uveitis and review the current literature. The aim of this review is to examine the recent evidence regarding treatment with rituximab in ocular non-infectious inflammation, describe treatment regimes and consider the role of this drug in controlling non-infectious uveitis.

\section{Case Report}

A 62-year-old man diagnosed with birdshot chorioretinopathy presented to the clinic in 2008. His main complaints were recurrent episodes of anterior and intermediate uveitis together with cystoid macular oedema. Best-corrected visual acuity (BCVA) at presentation was $6 / 6$ and 6/7.6 for the right and left eyes, respectively. Over the entire follow-up period, he suffered from recurrent bilateral asynchronous flares presenting with increased vitritis and cystoid macular oedema (up to 498 and $396 \mu \mathrm{m}$, right and left eyes, respectively) and resulting in decreased BCVA, down to 6/12 and $6 / 15$, right and left eyes, respectively. While both eyes were involved, his left eye was more severely affected, requiring intensive treatment in the form of systemic prednisolone starting at a dose of $60 \mathrm{mg}$ o.d. to which were later added 2 nd-line agents, first methotrexate $25 \mathrm{mg} \times 1$ /week and then mycophenolate mofetil (MMF) up to a dose of $1.5 \mathrm{~g}$ b.i.d. This was augmented by repeated orbital floor injections of depomedrone $40 \mathrm{mg}$ ( 3 injections in the left eye), intravitreal injections of triamcinolone acetate $4 \mathrm{mg}$ ( 1 in the left eye) and an ozurdex implant (1 in the left eye). The combined treatment resulted in temporary improvement in inflammation and BCVA lasting several weeks to months, with relapses occurring as the effect of the local therapy subsided. The use of longterm high-dose systemic steroids resulted in decreased bone density, requiring the initiation of alendronate therapy.

In an attempt to achieve inflammatory control and reduce the requirement for systemic steroids and MMF, a course of rituximab was begun. Two infusions of 1,000 mg were given 2 weeks apart, with subsequent blood analysis demonstrating a complete eradication of peripheral B cells. Three months after treatment his ocular inflammation subsided, his inflammation remained controlled with no vitritis, the cystoid macular oedema reduced, his prednisolone was reduced to $5 \mathrm{mg}$ and MMF to $500 \mathrm{mg}$ b.i.d. At his final follow-up, 9 months after rituximab had been started, the inflammation was controlled and his BCVA was maintained at $6 / 6$ in both eyes. His immunosuppressive treatment remained at prednisolone $5 \mathrm{mg}$ o.d. and MMF $500 \mathrm{mg}$ b.i.d.

\section{Rituximab and CD20}

CD20 antigen is a tetraspan membrane protein that acts as a calcium channel and is expressed on the surface of only mature B lymphocytes. While its naive ligand remains unknown, its activation is connected to B cell activation and proliferation [4]. In vitro studies using antiCD20 antibodies have suggested that CD20 may activate intracellular signalling pathways, leading to cell cycle ar- rest, apoptosis or lysosome-mediated cell death $[5,6]$. It has a variable expression, appearing first in the late stages of B cell maturation; it later disappears when B cells differentiate into plasma cells. By targeting CD20, only mature B cells are affected and precursor stem cells remain unaffected. Furthermore, long-living plasma cells found in the bone marrow are also left unharmed, that way antibody production remains intact and immune memory against previously fought infectious agents is preserved.

Rituximab is a chimeric (murine and human) monoclonal antibody directed against the CD20 antigen $[7,8]$. Antibody connection to the receptor initiates a signal cascade that results in B cell death. The exact mechanism of cell death remains unclear; however, it is thought to be caused by a combination of pathways including antibody-dependent cell-mediated cytotoxicity, complement-mediated lysis, growth inhibition and apoptosis $[4,9]$. Animal models suggest that antibody-dependent cell-mediated cytotoxicity is the most important pathway [10]. By inducing peripheral B cell depletion, it has been found to be effective in inducing remission of $\mathrm{B}$ cell monocloncal proliferation as well as systemic auto-immune diseases. It is usually given in the form of a single course of intravenous infusions that results in rapid, long-lasting depletion of peripheral B cells. Furthermore, as $B$ cells act as antigen-presenting cells, their removal has an impact on T cell activation, extending rituximab's potential use also to T-cell-mediated conditions such as Behçet's disease (BD) $[11,12]$.

\section{Rituximab in Systemic Disease}

While rituximab was approved by the Food and Drug Administration in 1997 for treatment in relapsed or refractory non-Hodgkin lymphoma [13], it is now also used for various systemic inflammatory diseases, including rheumatoid arthritis, garnulomatosis with polyangiitis (GPA, formerly Wegener's granulomatosis), antineutrophil cytoplasmic antibody-associated vasculitis, systemic lupus erythematosus and microscopic polyangiitis [1420]. Its widest use in auto-immune disease is for the treatment of refractory rheumatoid arthritis patients who have not responded to other immunosuppressive agents [21-23]. Treatment protocols differ among the various conditions with weekly treatments for 2-4 weeks at doses ranging from 500 to $2,000 \mathrm{mg}$. These achieve peripheral CD20 B cell depletion and clinical remission, which may last from 6 to 12 months. In cases of relapse, retreatment is able to induce further disease remission. 
Table 1. Rituximab in intra-ocular inflammation clinical studies

\begin{tabular}{|c|c|c|c|c|c|c|}
\hline Paper & Year & Disease & $\begin{array}{l}\text { Cases } \\
\mathrm{n}\end{array}$ & Rituximab treatment regime & Outcome & $\begin{array}{l}\text { Mean } \\
\text { follow- } \\
\text { up time } \\
\text { months }\end{array}$ \\
\hline Iaccheri et al. [51] & 2010 & Anterior nodular scleritis & 1 & $2 \times 1,000 \mathrm{mg}, 2$-week interval & Remission & 9 \\
\hline Ahmadi-Simab et al. [42] & 2005 & Anterior scleritis & 1 & $4 \times 375 \mathrm{mg} / \mathrm{m}^{2}, 4$-week interval & $\begin{array}{l}\text { Quiescence under } \\
\text { immunosuppressive therapy }\end{array}$ & 6 \\
\hline Taylor et al. [29] & 2009 & Ophthalmic GPA & 10 & $2 \times 1,000 \mathrm{mg}, 2$-week interval & $\begin{array}{l}\text { Quiescence under } \\
\text { immunosuppressive therapy }\end{array}$ & 12 \\
\hline Joshi et al. [43] & 2011 & Ophthalmic GPA & 20 & $2 \times 1,000 \mathrm{mg}, 2$-week interval & $\begin{array}{l}\text { Quiescence under } \\
\text { immunosuppressive therapy }\end{array}$ & 18 \\
\hline Cheung et al. [31] & 2005 & Scleritis associated with GPA & 1 & $2 \times 1,000 \mathrm{mg}, 2$-week interval & $\begin{array}{l}\text { Quiescence under } \\
\text { immunosuppressive therapy }\end{array}$ & 7 \\
\hline Onal et al. [30] & 2008 & Scleritis associated with GPA & 1 & $2 \times 1,000 \mathrm{mg}, 2$-week interval & Remission & 12 \\
\hline Chauhan et al. [52] & 2009 & $\begin{array}{l}\text { Scleritis associated with } \\
\text { rheumatoid arthritis }\end{array}$ & 3 & $2 \times 1,000 \mathrm{mg}, 2$-week interval & Remission & $6-24$ \\
\hline Baslund et al. [37] & 2012 & $\begin{array}{l}\text { Idiopathic orbital inflammation } \\
\text { associated with GPA }\end{array}$ & 10 & $2 \times 1,000 \mathrm{mg}, 2$-week interval & 4 of 10 clinical improvement & 17 \\
\hline Foster et al. [38] & 2010 & Ocular cicatricial pemphigoid & $\begin{array}{l}12 \text { in } 2 \\
\text { treatment } \\
\text { arms }\end{array}$ & $\begin{array}{l}2 \times 1,000 \mathrm{mg}, 2 \text {-week interval + } \\
\text { intravenous immunoglobulin; } \\
\text { systemic immunosuppression }\end{array}$ & $\begin{array}{l}\text { Stabilization of BCVA and } \\
\text { disease progression }\end{array}$ & 57.5 \\
\hline Heiligenhaus et al. [34] & 2011 & $\begin{array}{l}\text { Uveitis associated with juvenile } \\
\text { idiopathic arthritis }\end{array}$ & 10 & $2 \times 1,000 \mathrm{mg}, 2$-week interval & $70 \%$ remission & 11 \\
\hline Miserocchi et al. [35] & 2011 & $\begin{array}{l}\text { Uveitis associated with juvenile } \\
\text { idiopathic arthritis }\end{array}$ & 8 & $\begin{array}{l}2 \times 1,000 \mathrm{mg}, 2 \text {-week interval }+ \\
3 \text { rd at } 12 \text { months as needed }+ \\
4 \text { th at } 21 \text { months as needed }\end{array}$ & $\begin{array}{l}2 \text { patients in remission } \\
5 \text { patients quiescence under } \\
\text { immunosuppressive therapy }\end{array}$ & 11.75 \\
\hline Miserocchi et al. [36] & 2011 & $\begin{array}{l}\text { Uveitis associated with juvenile } \\
\text { idiopathic arthritis }\end{array}$ & 8 & $\begin{array}{l}2 \times 1,000 \mathrm{mg}, 2 \text {-week interval }+ \\
3 \mathrm{rd} \text { at } 12 \text { months as needed }+ \\
4 \text { th at } 21 \text { months as needed }\end{array}$ & $\begin{array}{l}1 \text { patient in remission } \\
6 \text { patients quiescence under } \\
\text { immunosuppressive therapy }\end{array}$ & 14.87 \\
\hline Sadreddini et al. [11] & 2008 & Uveitis associated with $\mathrm{BD}$ & 1 & $2 \times 1,000 \mathrm{mg}, 2$-week interval & $\begin{array}{l}\text { Quiescence under } \\
\text { immunosuppressive therapy }\end{array}$ & 24 \\
\hline Davatchi et al. [41] & 2010 & Uveitis associated with $\mathrm{BD}$ & $\begin{array}{l}20 \text { in } 2 \\
\text { treatment } \\
\text { arms }\end{array}$ & $\begin{array}{l}2 \times 1,000 \mathrm{mg}, 2 \text {-week interval; } \\
\text { systemic immunosuppression }\end{array}$ & Improvement in clinical indices & 6 \\
\hline
\end{tabular}

\section{Treatment with Rituximab for Ocular Disease}

Rituximab has been successfully used to treat ocular disease relating to systemic inflammatory conditions as well as others affecting the eyes alone (table 1). There is some evidence that it may be used as an intravitreal agent in cases of relapsing primary vitreoretinal lymphoma [24, 25 ], and it has been further reported for use in cases of peripheral ulcerative keratitis [26-28], scleritis related to rheumatoid arthritis and GPA [29-31], juvenile idiopathic arthritis (JIA) [32-36], orbital inflammation [37], ocular cicatricial pemphigoid [38] and BD [11,39-41]. Most reports suggest their patients achieved clinical remission, in some reflecting quiescent disease with treat- ment $[11,29,31,35,36,42,43]$. According to the Standardization of Uveitis Nomenclature, the definition of remission is reserved for inactive disease for at least 3 months after discontinuing all treatments for eye disease [44]. Therefore we have divided the outcome of all the reports into drug-free remission or quiescence under immunosuppressive therapy.

\section{Intra-Ocular Lymphoma}

Primary vitreoretinal lymphoma may involve the vitreous, retina, optic nerve and subretinal structures [45]. It mainly develops in elderly people and is regarded as a part of central nervous system lymphomas that are a subset of non-Hodgkin lymphoma. Over $15 \%$ of primary 
central nervous system lymphoma patients develop intraocular lymphoma, with $65-90 \%$ of primary vitreoretinal lymphoma patients later diagnosed with central nervous system involvement [24]. Primary vitreoretinal lymphomas are typically classified as a diffuse large B cell lymphoma, and therefore use of rituximab has been explored. Animal models and preliminary clinical studies have suggested that an intravitreal injection of $1 \mathrm{mg}$ rituximab has no untoward ocular effects $[46,47]$. It penetrates the entire retina [48], and has a half-life of approximately 5 days, meaning it is effective for up to 3-4 weeks [24]. Clinical trials have indicated it is effective in inducing disease remission alone or in combination with other chemotherapeutic agents [24], and may be used for re-inducing remission in patients with disease relapse that were formerly treated with radiotherapy and systemic chemotherapy $[25,49]$.

\section{Scleritis and Orbital Inflammation}

Inflammation of the sclera may present as an isolated pathology or as part of systemic diseases such as GPA or rheumatoid arthritis. It involves the anterior or posterior sclera and in some cases can result in sclera necrosis. Treatment aims at controlling the inflammation and preventing sclera thinning. Use of rituximab in these systemic conditions has prompted further investigation into its use among patients with refractory scleritis. In patients suffering from GPA involving the sclera, optic nerve or orbital inflammation, who were refractory to combinations of systemic steroids and immunosuppressive agents, the addition of 2 intravenous infusions of rituximab resulted in lasting disease control in all patients [29-31, 37, 42]. These patients had depletion of peripheral B cells, reduction in titers of cytoplasmic-pattern antineutrophil cytoplasmic antibodies and improvement in clinical signs. Other immunosuppressive agents were then lowered or discontinued [29-31]. In a recent case series, Joshi et al. [43] demonstrated efficacy of rituximab treatment among 20 patients with ophthalmic GPA refractory to immunosuppressive therapy. Two doses of 1,000 mg rituximab, given 2 weeks apart, resulted in complete disease control in all patients within 6 months. Disease relapse occurred in a third of patients within 18 months, and retreatment resulted in re-establishing disease control. While these studies demonstrated rituximab is effective for treating scleritis, a recent study has suggested rituximab has limited response in patients with refractory scleritis and orbital inflammation, possibly due to fibrotic changes in the orbit [50]. Results among patients with scleritis associated with rheumatoid arthritis have been reported where use of rituximab resulted in disease remission and systemic steroids and immunosuppressive agents were discontinued $[51,52]$.

\section{Juvenile Idiopathic Arthritis}

JIA is a systemic condition that involves inflammation of joints as well as ocular involvement. It is the most common systemic disorder associated with uveitis in childhood and up to a third of children suffer from poor longterm visual outcome [53]. While most children have no ocular symptoms during acute bouts of anterior uveitis, repeat flares can lead to progressive ocular complications including cataract, posterior synechiae, glaucoma and maculopathy leading to visual impairment [54]. Oligoarticular JIA and uveitis are associated with up-regulation of immature $B$ cells, generation, activation, and differentiation of clonal B cells and the release of pathogenic auto-antibodies [55]. This is suggested by elevated levels of antinuclear antibodies found in this condition [56]. Use of rituximab has been demonstrated in cases with joint involvement that were refractory to systemic steroids and immunosuppression, including methotrexate, cyclosporin and tumour necrosis factor a inhibitors. Following a single treatment course of 2 infusions, most patients responded by lasting disease remission, with resolution of symptoms and reduction or discontinuation of other immunosuppressive agents [32,33]. Treatment of ocular involvement was also explored in several small case series demonstrating a positive effect [34-36]. In a case series of 10 JIA patients with ocular involvement, a single treatment course of 2 rituximab 1,000-mg infusions, 2 weeks apart, resulted in uveitis remission in 7 of these patients [34]. Systemic and local immunosuppressive treatments were then tapered with complete withdrawal of all other drugs in some cases. In another case series, a single treatment course resulted in a decrease in inflammatory activity that was noted to begin up until the 4 th- 5 th month after treatment $[35,36]$. Disease control lasted 6-25 months with patients who relapsed responding to additional repeat infusions of rituximab [25].

\section{Behçet's Disease}

$\mathrm{BD}$ is a T-cell-driven systemic auto-immune disorder affecting multiple organs, and is related to severe intraocular inflammation [40]. Ocular involvement is paramount to the clinical diagnosis of the condition and is related to a high incidence of visual loss. While historically BD has been treated with high-dose systemic ste- 
roids and immunosuppressive agents, recently rituximab has emerged as a possible treatment option. This has forced clinicians to reconsider the role of B cells in classically T-cell-related conditions. It is thought that mature $B$ cells, in their role as antigen-presenting cells, play an important part in $\mathrm{T}$ cell activation and disease activity. By depleting mature $\mathrm{B}$ cells, lasting disease control was achieved in $\mathrm{BD}$ patients who were not responsive to other forms of immunosupression $[11,39,40]$. In a group of $20 \mathrm{BD}$ patients with retinal vasculitis and oedema, treatment with rituximab resulted in improved disease control at 6 months compared to patients who received a combined cytotoxic treatment including cyclophosphamide, azathioprine and prednisolone [41]. A single course of 2 rituximab 1,000-mg infusions (2 weeks apart) reduced retinal oedema and disease activity scores. Although patients responded to treatment with $\mathrm{B}$ cell depletion and inactive disease, they continued to require low-dose systemic steroids and other immunosuppressive drugs [41]. This was both to maintain remission, as well as to prevent rituximab-related side effects, primarily an infusion reaction.

\section{Dosage and Side Effects}

While rituximab is widely accepted for treatment of lymphoma and systemic auto-immune conditions, evidence from ocular conditions is less available (table 1). In adults with ocular inflammation most treatment protocols include a single course of two 1,000-mg infusions, 2 weeks apart. This generally results in completed peripheral $\mathrm{B}$ cell depletion and disease control with time. In cases when complete response is not achieved or if patients relapse, an additional infusion is given after several months, resulting in renewed disease quiescence $[36,43$, 57]. Information regarding paediatric dosage mainly comes from JIA patients. The reported regime in these children is a course of 2 infusions, 2 weeks apart, at a dose of approximately $375 \mathrm{mg} / \mathrm{m}^{2}$ body surface [32, 34].

While rituximab has a favourable adverse reaction profile, it is a chimeric antibody that may stimulate the production of human antichimeric antibodies, which can induce hyperreactivity responses [58]. Patients generally tolerate rituximab well with infusion reaction the most frequent adverse event, occurring in most patients during the first infusion, but rarely following subsequent treatments [59]. Most of these patients experience immediate mild reactions (fever, rigor and chills) that can be treated symptomatically. Severe reactions including se- rum sickness can be avoided using concomitant intravenous corticosteroids [60]. Other serious side effects, reported in patients treated for systemic disease included an increased risk of systemic infections [59], progressive multifocal leucoencephalopathy [61] and hepatitis B reactivation [62]. Of these, the risk of systemic infection, occurring in patients receiving additional immunosuppressive drugs, is of some concern and has even been reported to result in fatal septicaemia [59]. Therefore patients require a continued close follow-up with repeated blood tests.

\section{Conclusions}

Rituximab has been shown to be effective in controlling orbital conditions and external ocular inflammation (scleritis). It has also shown efficacy in controlling intra-ocular inflammation in JIA-associated uveitis. In most patients a single course results in inactive disease and other immunosuppressive treatment can be reduced or discontinued. While information regarding the effectiveness of this treatment in intra-ocular inflammation remains limited, results from our own patients, as demonstrated in the case report, indicate that rituximab treatment can result in disease quiescence allowing discontinuation of other immunosuppressive treatment, similar to that achieved in external ocular disease $[23,29]$.

$\begin{aligned} \text { References } & \begin{array}{l}\text { Larson T, Nussenblatt RB, Sen HN: Emerging } \\ \text { drugs for uveitis. Exp Opin Emerg Drugs }\end{array} \\ & 2011 ; 16: 309-322 .\end{aligned}$


7 Reff ME, Carner K, Chambers KS, Chinn PC, Leonard JE, Raab R, Newman RA, Hanna N, Anderson DR: Depletion of B cells in vivo by a chimeric mouse human monoclonal antibody to CD20. Blood 1994;83:435-445.

8 Blank M, Shoenfeld Y: B cell targeted therapy in autoimmunity. J Autoimmun 2007;28: 62-68.

$\$$ Bonavida B: What signals are generated by anti-CD20 antibody therapy? Curr Hematol Malig Rep 2006;1:205-213.

10 Perosa F, Prete M, Racanelli V, Dammacco F: $\mathrm{CD} 20$-depleting therapy in autoimmune diseases: from basic research to the clinic. J Intern Med 2010;267:260-277.

-11 Sadreddini S, Noshad H, Molaeefard M, Noshad R: Treatment of retinal vasculitis in Behçet's disease with rituximab. Mod Rheumatol/Jpn Rheum Assoc 2008;18:306-308.

$\checkmark 12$ Arkfeld DG: The potential utility of B cell-directed biologic therapy in autoimmune diseases. Rheumatol Int 2008;28:205-215.

13 Cultrera JL, Dalia SM: Diffuse large B-cell lymphoma: current strategies and future directions. Cancer Control 2012;19:204-213.

-14 Caporali R, Caprioli M, Bobbio-Pallavicini F, Bugatti S, Montecucco C: Long term treatment of rheumatoid arthritis with rituximab. Autoimmun Rev 2009;8:591-594.

15 Edwards JC, Leandro MJ, Cambridge G: B lymphocyte depletion therapy with rituximab in rheumatoid arthritis. Rheum Dis Clin North Am 2004;30:393-403, viii.

16 Kiely PD, Deighton C, Dixey J, Ostor AJ: Biologic agents for rheumatoid arthritis - negotiating the NICE technology appraisals. Rheumatology (Oxford) 2012;51:24-31.

-17 Conti F, Perricone C, Ceccarelli F, Valesini G: Rituximab treatment of systemic lupus erythematosus in controlled trials and in clinical practice: two sides of the same coin. Autoimmun Rev 2010;9:716-720.

-18 Stasi R, Stipa E, Del Poeta G, Amadori S, Newland AC, Provan D: Long-term observation of patients with anti-neutrophil cytoplasmic antibody-associated vasculitis treated with rituximab. Rheumatology (Oxford) 2006;45: 1432-1436.

19 Rhee EP, Laliberte KA, Niles JL: Rituximab as maintenance therapy for anti-neutrophil cytoplasmic antibody-associated vasculitis. Clin J Am Soc Nephrol 2010;5:1394-1400.

20 Roubaud-Baudron C, Pagnoux C, MeauxRuault N, Grasland A, Zoulim A, Le Guen J, Prud'homme A, Bienvenu B, de Menthon M, Camps S, Le Guen V, Aouba A, Cohen P, Mouthon L, Guillevin L: Rituximab maintenance therapy for granulomatosis with polyangiitis and microscopic polyangiitis. J Rheumatol 2012;39:125-130.

-21 Van Vollenhoven RF, Emery P, Bingham CO 3rd, Keystone EC, Fleischmann RM, Furst DE, Tyson N, Collinson N, Lehane PB: Longterm safety of rituximab in rheumatoid arthritis: 9.5-year follow-up of the global clinical trial programme with a focus on adverse events of interest in RA patients. Annals of the Rheumatic Diseases, E-pub ahead of 33 Narvaez J, Diaz-Torne C, Juanola X, Geli C, print.

22 Emery P, Deodhar A, Rigby WF, Isaacs JD, Combe B, Racewicz AJ, Latinis K, AbudMendoza C, Szczepanski LJ, Roschmann RA, Chen A, Armstrong GK, Douglass W, Tyrrell $\mathrm{H}$ : Efficacy and safety of different doses and retreatment of rituximab: a randomised, placebo-controlled trial in patients who are biological naive with active rheumatoid arthritis and an inadequate response to methotrexate (Study Evaluating Rituximab's Efficacy in MTX iNadequate rEsponders (SERENE)). Ann Rheum Dis 2010;69:1629-1635.

23 Smolen JS, Keystone EC, Emery P, Breedveld FC, Betteridge N, Burmester GR, Dougados M, Ferraccioli G, Jaeger U, Klareskog L, Kvien TK, Martin-Mola E, Pavelka K: Consensus statement on the use of rituximab in patients with rheumatoid arthritis. Ann Rheum Dis 2007;66:143-150.

24 Chan CC, Rubenstein JL, Coupland SE, Davis JL, Harbour JW, Johnston PB, Cassoux N, Touitou V, Smith JR, Batchelor TT, Pulido JS: Primary vitreoretinal lymphoma: a report from an International Primary Central Nervous System Lymphoma Collaborative Group symposium. Oncologist 2011;16:1589-1599.

25 Ohguro N, Hashida N, Tano Y: Effect of intravitreous rituximab injections in patients with recurrent ocular lesions associated with central nervous system lymphoma. Arch Ophthalmol 2008;126:1002-1003.

26 Freidlin J, Wong IG, Acharya N: Rituximab treatment for peripheral ulcerative keratitis associated with Wegener's granulomatosis. Br J Ophthalmol 2007;91:1414.

27 Albert M, Beltran E, Martinez-Costa L: Rituximab in rheumatoid arthritis-associated peripheral ulcerative keratitis (in Spanish). Arch Soc Esp Oftalmol 2011;86:118-120.

-28 Huerva V, Sanchez MC, Traveset A, Jurjo C, Ruiz A: Rituximab for peripheral ulcerative keratitis with Wegener granulomatosis. Cornea 2010;29:708-710.

29 Taylor SR, Salama AD, Joshi L, Pusey CD, Lightman SL: Rituximab is effective in the treatment of refractory ophthalmic Wegener's granulomatosis. Arthritis Rheum 2009; 60:1540-1547.

30 Onal S, Kazokoglu H, Koc A, Yavuz S: Rituximab for remission induction in a patient with relapsing necrotizing scleritis associated with limited Wegener's granulomatosis. Ocular Immunology and Inflammation 2008; 16:230-232.

31 Cheung CM, Murray PI, Savage CO: Successful treatment of Wegener's granulomatosis associated scleritis with rituximab. Br J Ophthalmol 2005;89:1542.

32 Alexeeva EI, Valieva SI, Bzarova TM, Semikina EL, Isaeva $\mathrm{KB}$, Lisitsyn AO, Denisova RV, Chistyakova EG: Efficacy and safety of repeat courses of rituximab treatment in patients with severe refractory juvenile idiopathic arthritis. Clin Rheumatol 2011;30: $1163-1172$.
Llobet JM, Nolla JM, Diaz-Lopez C: Rituximab therapy for refractory systemic-onset juvenile idiopathic arthritis. Ann Rheum Dis 2009;68:607-608.

34 Heiligenhaus A, Miserocchi E, Heinz C, Gerloni V, Kotaniemi K: Treatment of severe uveitis associated with juvenile idiopathic arthritis with anti-CD20 monoclonal antibody (rituximab). Rheumatology (Oxford) 2011;50:13901394.

35 Miserocchi E, Pontikaki I, Modorati G, Bandello F, Meroni PL, Gerloni V: Rituximab for uveitis. Ophthalmology 2011;118:223-224.

36 Miserocchi E, Pontikaki I, Modorati G, Gattinara M, Meroni PL, Gerloni V: Anti-CD 20 monoclonal antibody (rituximab) treatment for inflammatory ocular diseases. Autoimmun Rev 2011;11:35-39.

37 Baslund B, Wiencke AK, Rasmussen N, Faurschou M, Toft PB: Treatment of orbital inflammation with rituximab in Wegener's granulomatosis. Clin Exp Rheumatol 2012;30: S7-S10.

38 Foster CS, Chang PY, Ahmed AR: Combination of rituximab and intravenous immunoglobulin for recalcitrant ocular cicatricial pemphigoid: a preliminary report. Ophthalmology 2010;117:861-869.

39 Benitah NR, Sobrin L, Papaliodis GN: The use of biologic agents in the treatment of ocular manifestations of Behçet's disease. Semin Ophthalmol 2011;26:295-303.

40 Evereklioglu C: Ocular Behçet disease: current therapeutic approaches. Curr Opin Ophthalmol 2011;22:508-516.

41 Davatchi F, Shams H, Rezaipoor M, SadeghiAbdollahi B, Shahram F, Nadji A, Chams-Davatchi C, Akhlaghi M, Faezi T, Naderi N: Rituximab in intractable ocular lesions of Behçet's disease: randomized single-blind control study (pilot study). Int J Rheum Dis 2010; 13:246-252.

42 Ahmadi-Simab K, Lamprecht P, Nolle B, Ai M, Gross WL: Successful treatment of refractory anterior scleritis in primary Sjogren's syndrome with rituximab. Ann Rheum Dis 2005; 64:1087-1088.

43 Joshi L, Lightman SL, Salama AD, Shirodkar AL, Pusey CD, Taylor SR: Rituximab in refractory ophthalmic Wegener's granulomatosis: PR3 titers may predict relapse, but repeat treatment can be effective. Ophthalmology 2011;118:2498-2503.

44 The Standardization of Uveitis Nomenclature (SUN) working group: Standardization of uveitis nomenclature for reporting clinical data. Results of the First International Workshop. Am J Ophthalmol 2005;140:509-516.

45 Davis JL: Intraocular lymphoma: a clinical perspective. Eye (Lond) 2013;27:153-162.

46 Kim H, Csaky KG, Chan CC, Bungay PM, Lutz RJ, Dedrick RL, Yuan P, Rosenberg J, Grillo-Lopez AJ, Wilson WH, Robinson MR: The pharmacokinetics of rituximab following an intravitreal injection. Exp Eye Res 2006; 82:760-766. 
47 Kitzmann AS, Pulido JS, Mohney BG, Baratz $\mathrm{KH}$, Grube T, Marler RJ, Donaldson MJ, O’Neill BP, Johnston PB, Johnson KM, Dixon LE, Salomao DR, Cameron JD: Intraocular use of rituximab. Eye (Lond) 2007;21:1524-1527.

48 Grimm SA, Pulido JS, Jahnke K, Schiff D, Hall AJ, Shenkier TN, Siegal T, Doolittle ND, Batchelor T, Herrlinger U, Neuwelt EA, Laperriere N, Chamberlain MC, Blay JY, Ferreri AJ, Omuro AM, Thiel E, Abrey LE: Primary intraocular lymphoma: an International Primary Central Nervous System Lymphoma Collaborative Group Report. Ann Oncol 2007;18:1851-1855.

49 Pe'er J, Hochberg FH, Foster CS: Clinical review: treatment of vitreoretinal lymphoma. Ocul Immunol Inflamm 2009;17:299-306.

-50 Aries PM, Hellmich B, Voswinkel J, Both M, Nolle B, Holl-Ulrich K, Lamprecht P, Gross WL: Lack of efficacy of rituximab in Wegener's granulomatosis with refractory granulomatous manifestations. Ann Rheum Dis 2006; 65:853-858.

51 Iaccheri B, Androudi S, Bocci EB, Gerli R, Cagi$\mathrm{niC}$, Fiore T: Rituximab treatment for persistent scleritis associated with rheumatoid arthritis. Ocul Immunol Inflamm 2010;18:223-225.
2 Chauhan S, Kamal A, Thompson RN, Estrach C, Moots RJ: Rituximab for treatment of scleritis associated with rheumatoid arthritis. $\mathrm{Br} \mathrm{J}$ Ophthalmol 2009;93:984-985.

53 Kump LI, Castaneda RA, Androudi SN, Reed GF, Foster CS: Visual outcomes in children with juvenile idiopathic arthritis-associated uveitis. Ophthalmology 2006;113:1874-1877.

54 Gregory AC 2nd, Kempen JH, Daniel E, Kacmaz RO, Foster CS, Jabs DA, Levy-Clarke GA, Nussenblatt RB, Rosenbaum JT, Suhler EB, Thorne JE: Risk factors for loss of visual acuity among patients with uveitis associated with juvenile idiopathic arthritis: the Systemic Immunosuppressive Therapy for Eye Diseases Study. Ophthalmology 2013;120:186-192.

55 Browning JL: B cells move to centre stage: novel opportunities for autoimmune disease treatment. Nat Rev Drug Discov 2006;5:564576.

56 Lawrence JM 3rd, Moore TL, Osborn TG, Nesher G, Madson KL, Kinsella MB: Autoantibody studies in juvenile rheumatoid arthritis. Semin Arthritis Rheum 1993;22:265-274.

57 Vital EM, Dass S, Rawstron AC, Buch MH Goeb V, Henshaw K, Ponchel F, Emery P: Management of nonresponse to rituximab in rheumatoid arthritis: predictors and outcome of re-treatment. Arthritis Rheum 2010;62: 1273-1279.
8 Goto S, Goto H, Tanoshima R, Kato H, Takahashi H, Sekiguchi O, Kai S: Serum sickness with an elevated level of human anti-chimeric antibody following treatment with rituximab in a child with chronic immune thrombocytopenic purpura. Int J Hematol 2009;89:305309.

59 Kimby E: Tolerability and safety of rituximab (MabThera). Cancer Treat Rev 2005;31:456473.

60 Todd DJ, Helfgott SM: Serum sickness following treatment with rituximab. J Rheumatol 2007;34:430-433.

61 Carson KR, Focosi D, Major EO, Petrini M, Richey EA, West DP, Bennett CL: Monoclonal antibody-associated progressive multifocal leucoencephalopathy in patients treated with rituximab, natalizumab, and efalizumab: a review from the Research on Adverse Drug Events and Reports (RADAR) Project. Lancet Oncol 2009;10:816-824.

62 Villadolid J, Laplant KD, Markham MJ, Nelson DR, George TJ Jr: Hepatitis B reactivation and rituximab in the oncology practice. Oncologist 2010;15:1113-1121. 